\title{
New method developed for foundation strengthening in silty-clayed soils
}

\author{
Mikhail Samokhvalov ${ }^{1, *}$, Andrey Geydt ${ }^{1}$, and Alexander Paronko ${ }^{1}$ \\ ${ }^{1}$ Industrial University of Tyumen, St. Volodarsky 38, Tyumen, 625000, Russia
}

\begin{abstract}
The paper describes the new method developed for foundation strengthening by a drill and inject pile with controlled widening on its end. The method aims at increasing the useable area of the buildings under refurbishment. This is achieved by developing the underground space and/or adding floors. In-situ tests were carried out on a construction site in the city of Tyumen in order to implement the method on an industrial scale. The insitu tests resulted in determining the radius of the compacted zone of soil massif, the geometric parameters of controlled widening, the vertical and horizontal deformations of the soil massif in the pile area and the changed physical and mechanical characteristics. The article describes the production of a new method for reinforcing foundations in the form of a drill-injected pile with controlled broadening at the end.
\end{abstract}

\section{Introduction}

Well-timed refurbishment of any building is very important for maintaining its life cycle. When refurbishing buildings, it is necessary to provide for possible increase of their usable area by developing underground space and/or adding floors. The authors propose to use drill and inject piles as a new method to tackle this problem at the stage of foundation strengthening (Fig. 1) [1].

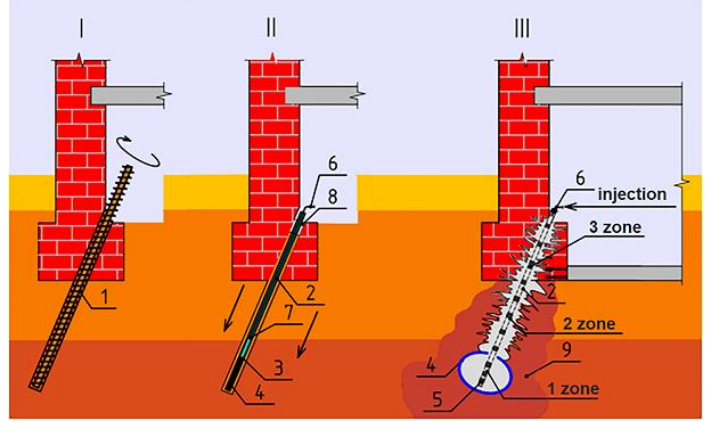

Fig. 1. Schematic illustration of drill-injection pile installation with the controlled broadening: 1borehole, 2-injector tube, 3-clamp, 4- membrane cup, 5-rubber sleeves, 6 - hose, 7-packer, 8-concrete plug, 9-compressed zone of soil massif.

\footnotetext{
*Corresponding author : sammy90@yandex.ru
} 
The method aims at soil compaction under the strip foundation followed by a significant increase in its bearing capacity and its inclusion in structural performance before the imposed load is applied. A membrane-shell which is located at the lower end of the pipe-injector distinguishes this method from the analogous ones. When mortar is injected, the membrane increases in size (stretches) in the soil massif and widens to the predicted diameter on the lower end. Dimensions of widening can be controlled by the injection pressure and mortar volume flow. The process of pile shaft formation is similar to traditional drill and inject piling with lip technology in the mortar injection mode under a pressure of 2-4 MPa (20-40 atmospheres) when vertical or horizontal hydraulic fractures occur in clayey soil. Such a method makes it possible to work in cramped conditions and is highly constructible. It allows several processes to be combined in a single operation: formation of widening at the pile end, formation of the pile shaft and foundation strengthening (injection of cracks). Besides, the method can save a large volume of mortar (volume is reduced up to 20 times), which is used mainly for widening formed at the pile end. This method can reduce performance time for foundation strengthening and turnaround time for building refurbishment. The method makes it possible to work with the minimum values of additional settlements due to «instant performance» of the pile during the process of widening (mortar injections into the membrane-shell); this makes the method different from the analogues ones.

\section{Goals and objectives of the study}

The goal of the study is to develop the new method of foundation strengthening in refurbished buildings and provide for possible increase of their usable area by developing underground space and/or adding floors.

Objectives of the study:

1. To study the stress-strain state (SSS) of the soil massif in the pile area after static tests;

2. To determine the changed physical and mechanical characteristics of the soil massif in the pile area;

3. To determine geometric parameters of widening formed at the pile end.

\section{Procedure for in-situ testing}

In-situ tests were carried out on a construction site in the city of Tyumen. The physical and mechanical characteristics of the soil bed are shown in Table 1.

Table 1. Physical and mechanical properties of a soil base.

\begin{tabular}{|c|c|c|c|c|c|c|c|}
\hline \multicolumn{2}{|c|}{ Type of soil } & \multirow{2}{*}{$\begin{array}{c}\text { Depth } \\
\mathrm{H}, \mathrm{m} \\
\\
0,5- \\
1,4\end{array}$} & \multirow{2}{*}{$\begin{array}{c}\text { Specifi } \\
\text { c } \\
\text { weight } \\
\gamma, \\
\mathrm{kN} / \mathrm{m}^{3} \\
17,6- \\
18,2 \\
\end{array}$} & \multirow{2}{*}{$\begin{array}{c}\begin{array}{c}\text { Fluidit } \\
\text { y } \\
\text { index I } \\
\text { L }\end{array} \\
0,15\end{array}$} & \multirow{2}{*}{$\begin{array}{c}\text { Angle of internal } \\
\text { friction } \varphi \text {, degrees } \\
14,7-21,5\end{array}$} & \multirow{2}{*}{$\begin{array}{c}\text { Specific } \\
\text { cohesio } \\
\mathrm{n} \mathrm{c}, \\
\mathrm{kPa} \\
24,0- \\
28,0 \\
\end{array}$} & \multirow{2}{*}{$\begin{array}{c}\begin{array}{c}\text { Deformation } \\
\text { modulus E, } \\
\mathrm{MPa}\end{array} \\
18,5-19,0\end{array}$} \\
\hline 1 & $\begin{array}{l}\text { Semi-solid } \\
\text { clay }\end{array}$ & & & & & & \\
\hline 2 & $\begin{array}{l}\text { Soft plastic } \\
\text { loam }\end{array}$ & $\begin{array}{l}1,4- \\
6,6\end{array}$ & $\begin{array}{c}18,4- \\
19,6\end{array}$ & 0,62 & $14,7-19,2$ & $\begin{array}{l}19,0- \\
23,0\end{array}$ & $7,7-8,0$ \\
\hline
\end{tabular}

Note: E - compression modulus of deformation, corrected via multiplying coefficients taken from Table. 5.1 of Building Regulations [2].

To make a drill and inject pile, a metal pipe of $57 \mathrm{~mm}$ in diameter, $3.5 \mathrm{~mm}$ in wall thickness, $2.5 \mathrm{~m}$ in length and $300 \mathrm{~mm}$ in perforation pitch of the holes was used as a pipeinjector. At a distance of $0.75 \mathrm{~m}$ from the pipe-injector top no openings were made. Here, a concrete tube made of heavy concrete was placed in order to prevent mortar extrusion from 
the hole under the acting injection pressure. Perforations were covered with lips. A rubber membrane was mounted above the lips. The membrane gently covered the lower end of the injector and repeated its shape - "shell". The membrane-shell was fixed to the pipe by automobile clamps (Fig. 2).
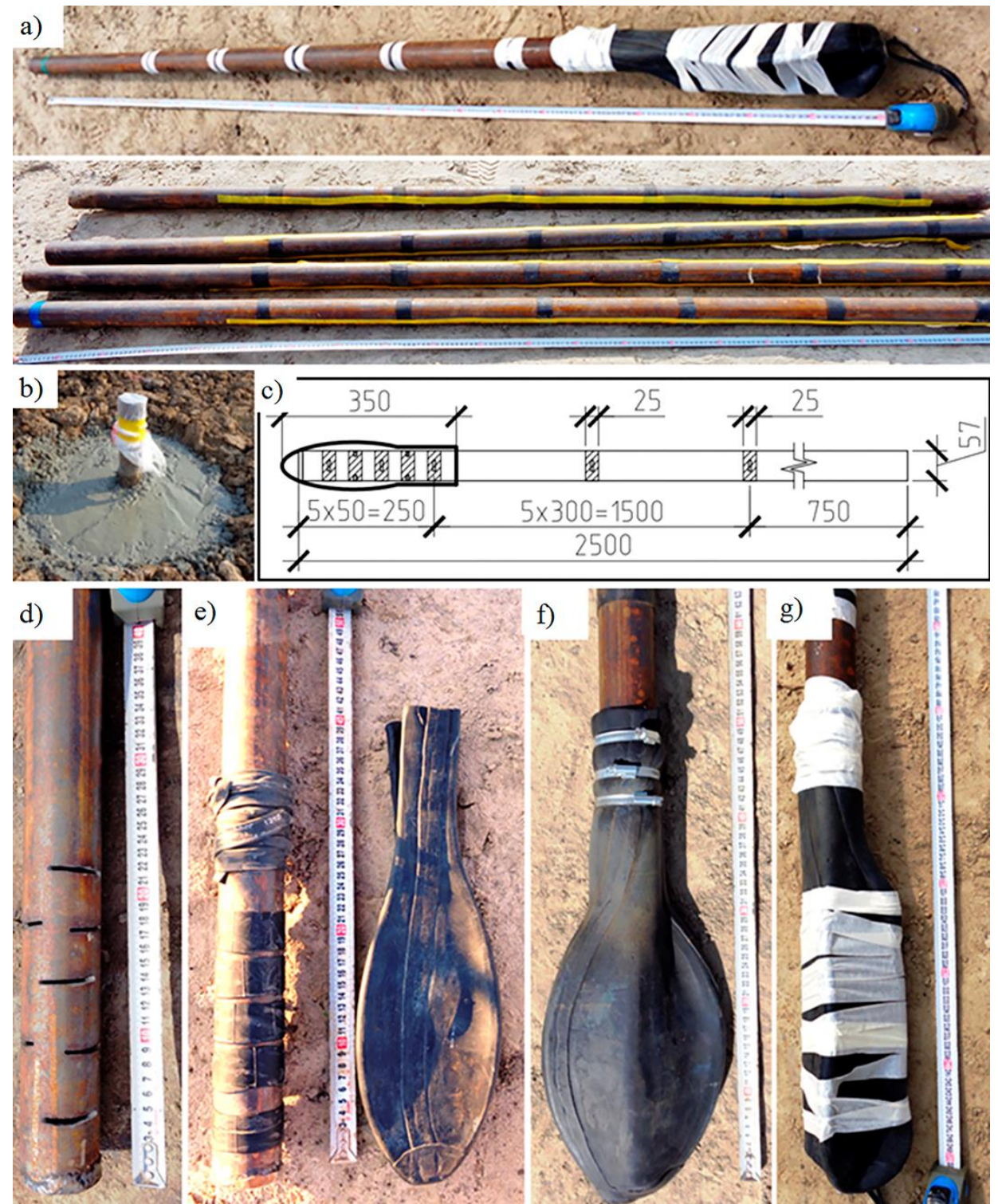

e)
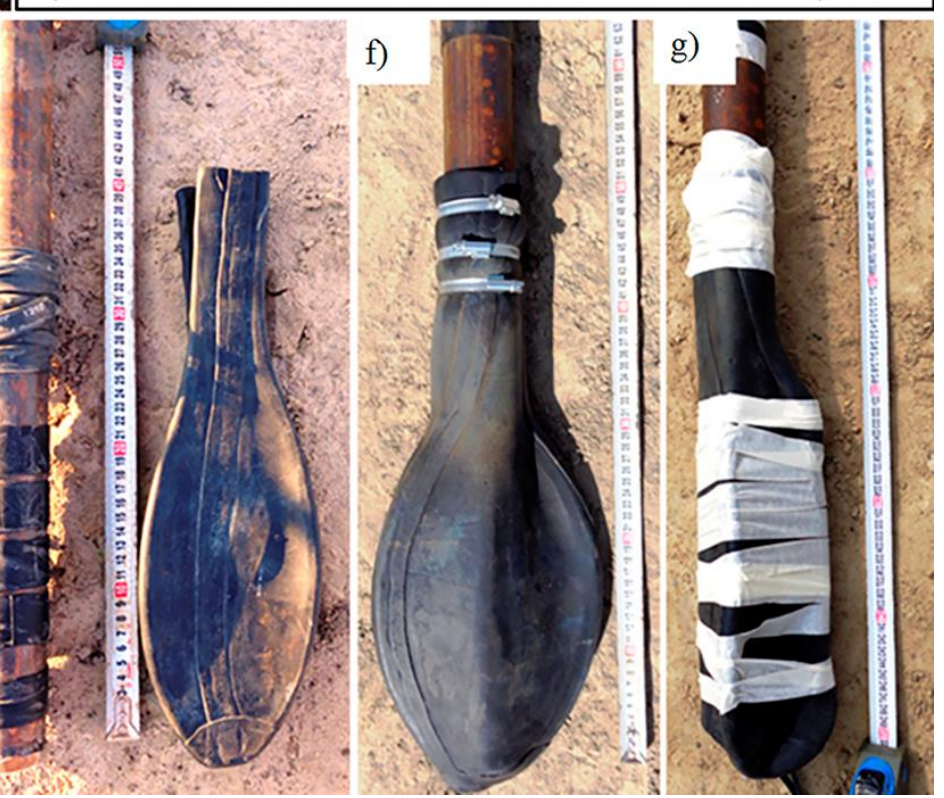

Fig. 2. The construction of the pipe-injector with a rubber membrane cup: a - injectors, b- concrete plug, $\mathrm{c}$ - schematic structural diagram, $\mathrm{d}$ - perforation of the holes, $\mathrm{e}$ - rubber sleeves, $\mathrm{f}$ - membrane cup, g- membrane cup before immersion of the injector into the well.

It should be noted that the membrane-shell was shaped as an "accordion" and fixed in this position by the paper sticky tape for smooth immersion of the injector into the well. Rubber lips were also fixed by the paper sticky tape in order to prevent their slipping due to friction of the injector over the walls of the well. 
In accordance with the GOST [3], the finished piles were given a 20-day "rest" necessary for redistribution of stresses in the soil massif and gain of the specified strength of the mortar.

The load was transferred on the pile by a hydraulic jack in steps of $5 \mathrm{kN}$ (Fig. 3). Deflectometer readings were recorded prior to loading and after application of each stage of loading in accordance with the procedure given in the GOST [3]. The settlement equal to 15 $\mathrm{mm}$ was taken as a particular value of the test pile resistance to penetration (failure criterion), appendix J. of Building Regulations [2].

The specially manufactured drill and inject pile was excavated in order to determine the changed physical and mechanical characteristics of the soil massif in the pile area. This pile was not subjected to static tests. Soil samples were selected for laboratory tests in steps of $0.5 \mathrm{~m}$ in depth from three vertical axes at 10,30 and $50 \mathrm{~cm}$ from the injector. The characteristics of soil samples taken at a distance of $8 \mathrm{~m}$ from the pile were accepted as the initial values.

The values of the physical characteristics were determined by the GOST procedure [4]: density of soil samples - by cutting rings, moisture content - by drying to the constant weight. The modulus of deformation was determined from the undisturbed soil samples put in compression devices in accordance with the GOST procedure [5]. The results obtained were statistically processed in accordance with the GOST procedure [6]; the samples which greatly differed in characteristics from the overall results were excluded from the total sample. After statistical processing of the data obtained, the curve of the changed modulus of deformation in depth was plotted (Fig. 4).

\section{Results of in-situ testing}

The static tests resulted in the curves of the pile settlement versus loading (Fig. 3). Both curves are lines which show gradual increase of the settlement and sections of linear performance. It should be noted that a large value of elastic yield in unloading, namely: $4.5 \mathrm{~mm}$ for widening of 301 in volume, $6.9 \mathrm{~mm}$ for widening of 401 in volume, is due to the compacted zone in the soil bed and residual stresses in the soil massif which occur in formation of the controlled widening [7-10].

The results of sampling and further determination of the changed physical and mechanical characteristics of the soil revealed the following:

in the zone of controlled widening:

- density increased on average by $24 \%$ and was $2.24 \mathrm{~g} / \mathrm{cm} 3$;

- moisture content decreased on average by $36 \%$;

- modulus of deformation increased by $67 \%$.

along the drill and injection pile shaft:

- density increased on average by $20 \%$ in a radius of $10 \mathrm{~cm}$, within $30 \mathrm{~cm}$ - by $14 \%$, within $50 \mathrm{~cm}$ - by $8 \%$;

- moisture content decreased on average by $28 \%$ in a radius of $10 \mathrm{~cm}$, within $30 \mathrm{~cm}$ - by $16 \%$, within $50 \mathrm{~cm}$ - by $8 \%$;

It is necessary to underline that non-uniformity in the obtained values of moisture content from 20 to $36 \%$ at $10 \mathrm{~cm}$ from the injector is due to randomness of hydraulic fractures;

- modulus of deformation increased on average by $51 \%$ in a radius of $10 \mathrm{~cm}$, within 30 $\mathrm{cm}$ - by $34 \%$, within $50 \mathrm{~cm}$ - by $15 \%$.

To determine the geometric parameters of controlled widening, pile shaft and hydraulic fractures, their excavation was done (fig. 5).

Due to the permanent injection pressure with a mean value of $1.2 \mathrm{MPa}$, the diameter of the drill and inject pile shaft increased on average 2.3 times from 80 to $180 \mathrm{~mm}$ [8-20]. 


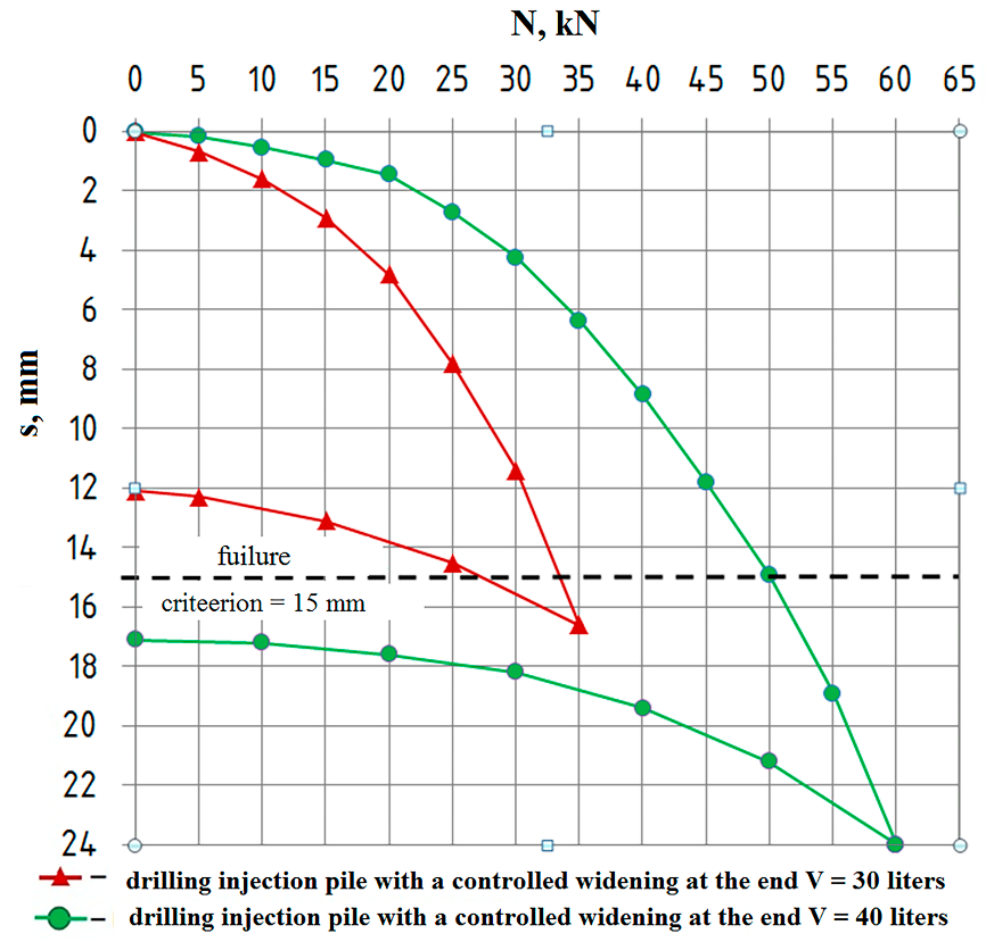

Fig. 3. Dependence graphs $s=f(p)$.

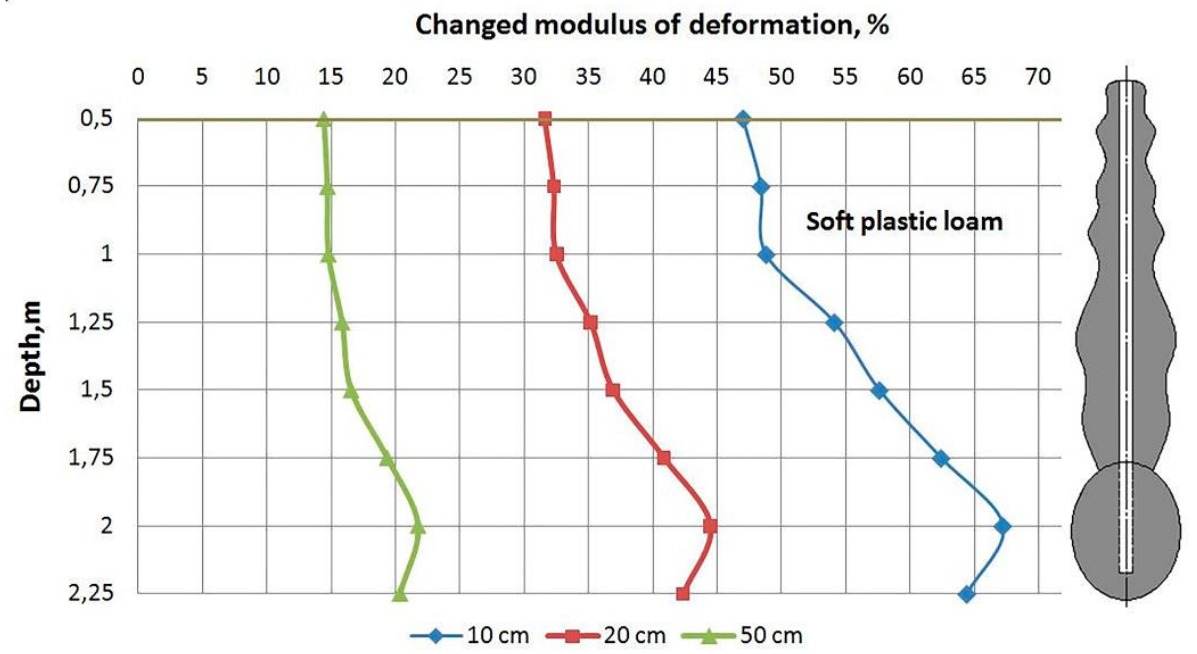

Fig. 4. Curves of the changed modulus of deformation in depth.

Figure 5 illustrates the main portion of hydraulic fractures formed in the soil massif under the injection pressure of 0.8-1.0 MPa. In here, crack growth was larger, and solid lentils of $15-30 \mathrm{~mm}$ in thickness were formed and extended to a distance of $0.5 \mathrm{~m}$ from the injector. The origin of the lentils formed was a significant excess of the local injection pressures (0.81.2 $\mathrm{MPa}$ ) above the normal stresses (up to $0.15 \mathrm{MPa}$ ) in the soil massif in a plane of possible displacements [1, 10 and14]. 

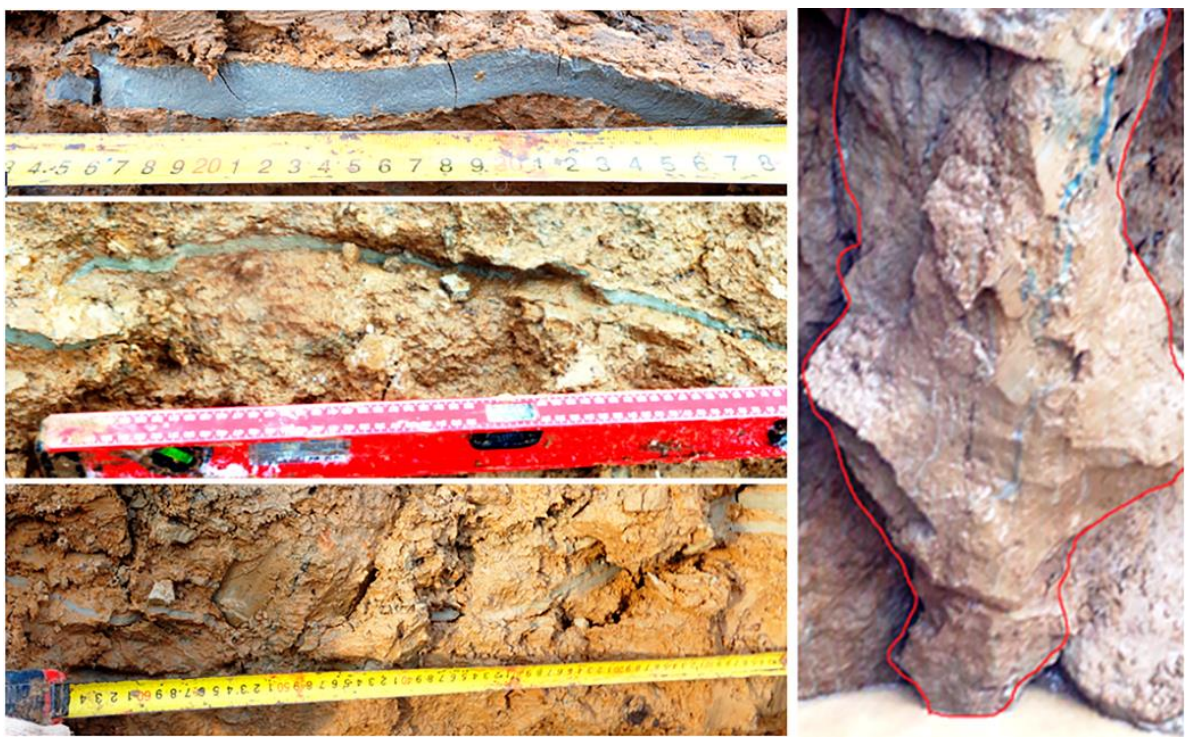

Fig. 5. Hydraulic fractures formed in the soil massif.

As is seen from Figure 6, when mortar was injected in a volume of 301, widening was formed of 340-360 $\mathrm{mm}$ in diameter, $410-430 \mathrm{~mm}$ in height, ratio $\mathrm{d} / \mathrm{h}=0.8$; in a volume of $401-370-390 \mathrm{~mm}$ in diameter, $510-530 \mathrm{~mm}$ in height, $\mathrm{d} / \mathrm{h}=0.7$.
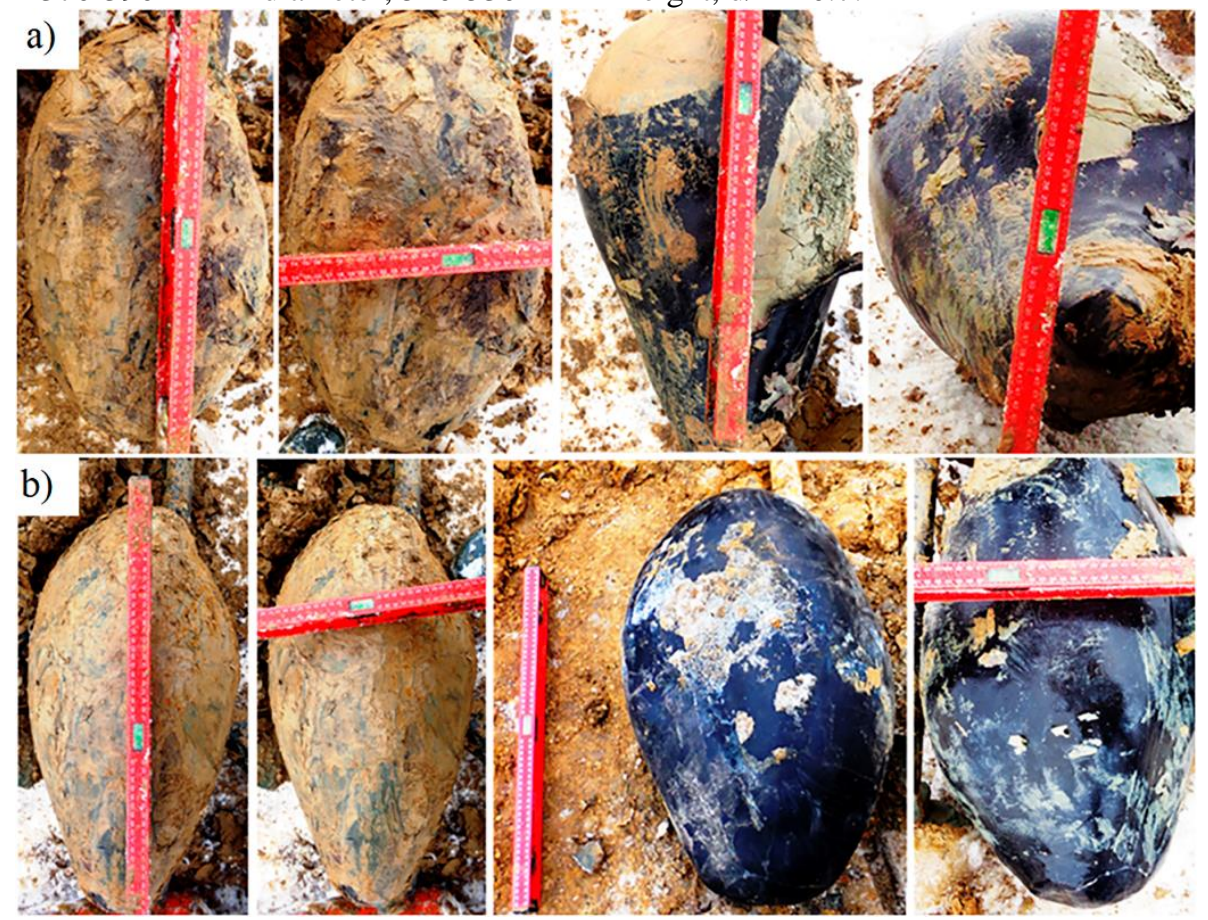

Fig. 6. Geometric parameters of widenings: a) with the volume of 30 liters; b) 40 liters. 


\section{Conclusions}

The in-situ tests have resulted in the following:

1. The settlement does not exceed $5 \mathrm{~mm}$ prior to the load equal to half of the drill and inject pile bearing capacity $\mathrm{Fd} / 2$, on average up to $30 \mathrm{kN}$ (Fig. 3). This is very important when working under the conditions of refurbishment, because large deformations are not allowed, appendix J. of Building Regulations [2];

2. The graph of the operation of the piles with a widening under a static compressing load has an initial linear and non-linear (elastic plastic) deformation area. At initial stages of unloading there is an active growth of recurring deformations whose character is fundamentally different from the graph of unloading of regular piles. A large value of elastic yield in unloading of $6 \mathrm{~mm}$ (Fig. 3) is due to the compacted zone in the soil bed and residual stresses in the soil massif which occur in formation of the controlled widening [7-10];

3. When the volume of controlled widening increases by 10 liters, the drill and inject pile bearing capacity increases on average by $10-12 \%$ due to the increased drag area and radius of the compacted zone of the soil massif;

4. The drill and inject piles with controlled widening significantly improve physical and mechanical characteristics of the soil massif. During consolidation it is strengthened by hydraulic fractures of the mortar, and the zones between fractures are compacted: density increases on average by $14 \%$, moisture content decreases by $17 \%$, modulus of deformation increases by $33 \%$.

Therefore during loading of a foundation deformation of a base will emerge in the elastic linear stage with a minimum heaving, which is crucial for strengthening foundations as part of reconstruction.

\section{References}

1. Ya.A. Pronozin, Yu.V. Zazulya, M.A. Samohvalov, D.V. Rachkov, Pat. 2605474 Rossijskaya Federaciya, MPK-2006.01 E 02 D 5/46. Sposob izgotovleniya buroinekcionnoj svai s kontroliruemym ushireniem, Byul. 35 (2016)

2. Russian Standard SP 22.13330.2011

3. Russian Standard GOST 5686-94

4. Russian Standard GOST 5180-84

5. Russian Standard GOST 12248-96

6. Russian Standard GOST 20522-2012

7. M.N. Ibragimov, V.V. Semkinm, Zakreplenie gruntov in"ekciej cementnyh rastvorov. Monografiya (ASV, Moscow, 2012)

8. V.V, Semkin, M.N. Ibragimov, Y.Y. Motuzov, Zakreplenie massivov slabogo grunta pod stroyashchimisya sooruzheniyami, Sbornik nauchnyh trudov NIIOSP (2006)

9. R.A. Mangushev, A.I. Osokin, Sovremennye svajnye tekhnologii (ASV, Moscow, 2007)

10. V.P. Petruhin, O.A. Shulyat'ev, O.A. Mozgacheva, Novye sposoby geotekhnicheskogo stroitel'stva: Nauchnoe izdanie (ASV, Moscow, 2015)

11. H. Brandl, Proceedings of the Twelfth International Conference on Soil Mechanics and Foundation Engineering (Rotterdam, 1992)

12. H.G. Poulos, E.N. Devis, Pile foundation analysis and design (Wiley, 2000)

13. I.I. Saharov, M.A, Abbud, Gidrorazryvnoj metod zakrepleniya osnovanij ehkspluatiruemyh zdanij i sooruzhenij, Geotekhnika. (SPbGASU, SPb, 2000) 
14. E.S. Voznesenskaya, V.A. Ermolaev, A.I. Osokin, S.V. Tatarinov, OFMG 4, 19-23 (2014)

15. L. Gabrielaitis, V. Papinigis, G. Zarzojus, Procedia Engineering 57, 287 - 293 (2013)

16. Z.G. Ter-Martirosyan, A.S.M. Abdul Malek, OFMG 6, 8 - 11 (2007)

17. Z.G. Ter-Martirosyan, V.S. Avanesov, Vestnik MGSU, 47-54 (2015)

18. A.I. Polishchuk, Osnovy proektirovaniya i ustrojstva fundamentov rekonstruiruemyh zdanij (STT, 2004)

19. R.H. Karol, Chemical grouting and soil stabilization (Basel. Marcel Dekker, Inc., New York, 2003)

20. L. Gabrielaitis, V. Papinigis, J. Sirvydaite, Engineering Structures and Technologies 4(1), 7-15 (2012) 